Bangladesh J. Bot. 49(1): 135-140, 2020 (March)

\title{
EVALUATION OF AGRICULTURAL BYPRODUCTS FOR THE PRODUCTION OF BETAGLUCOSIDASE BY ASPERGILLUS NIGER MBT-2 USING SOLID STATE FERMENTATION
}

\author{
Roheena Abdullah*, Maria Hanif, Afshan Kaleem, Mehwish Iqtedar, \\ Kinza Nisar and Faiza Saleem \\ Department of Biotechnology, Lahore College for Women University, Lahore, Pakistan
}

Keywords: Beta-glucosidase, Aspergillus niger, Fungal culture, Wheat bran

\begin{abstract}
The experiment was conducted to isolate and screen fungal strain and optimization of solid-state fermentation conditions for enhanced production of $\beta$-glucosidase. Different fungal cultures were isolated and screened for $\beta$-glucosidase production. The physicochemical and nutritional parameters were optimized for enhanced production of $\beta$-glucosidase from higher producer. Among all the isolates the isolate which exhibited highest $\beta$-glucosidase potential was identified and assigned the code as Aspergillus niger MBT-2. The optimum $\beta$-glucosidase production was obtained in M5 medium containing wheat bran after $72 \mathrm{hrs}$ of incubation at $40^{\circ} \mathrm{C}, \mathrm{pH} 6$ and $20 \mathrm{ml}$ of moisture contents. In addition to this $2 \%$ fructose and $2 \%$ yeast extract proved to be best carbon and nitrogen sources, respectively and gave maximal enzyme productivity. The exploitation of agricultural by products as a substrate reduced the production cost of enzyme and makes the process economical. The Aspergillus niger MBT-2 has promising potential of bioconversion of low-cost material into valuable product like $\beta$-glucosidase.
\end{abstract}

\section{Introduction}

$\beta$-glucosidase (EC 3.2.1.21) is one of the important enzymes. It breaks the $\beta 1,4$-glycosidic bond of cellobiose and ultimately results in the production of glucose from the non-reducing ends (Raza et al. 2011). This enzyme plays many vital roles in many physiological phenomenon. The most important role in microorganisms is the breakdown of cellulose, gene induction of cellulase and the recycling of carbon (Ahmed et al. 2017). $\beta$-glucosidase are also biologically active that speed up the glycosyl transfer reaction between oxygen nucleophiles. This reaction causes the cleavage of beta-glucosidic bond occurs between the sugar residues present in aryl and alkyl beta glucosides, cyanide releasing glucosides, and short chain oligosaccharides (Singhania et al. 2013). $\beta$-glucosidase has enormous range of applications in different industries including cosmetics, cotton, grain wet milling, food, diagnostics and pharmaceutical etc. In addition to this it is also used as an additive in animal feed, tobacco and food products, and synthesis of organic chemicals (Leite et al. 2007).

$\beta$-glucosidase can be produced from various sources such as fungi and bacteria. Mostly, filamentous fungi are used for the $\beta$-glucosidase production at a large scale. It is due to their enlarged hyphae which penetrate into the crystalline structure of cellulose and produce pressure due to which enzyme is produced in large amounts (Amouri and Gargouri 2006; Zang et al. 2018). The industrial residues that are used as a substrate proved to be beneficial for the filamentous fungi. The morphological characteristics of filamentous fungi help them to integrate their mycelia structure into the tough surface. So, the industrial raw material, which is considered as a waste product, utilized as a substrate thus reducing the pollution and enhancing the enzyme production (Bhargav et al. 2008). Nowadays, industrial enzymes are produced in a more renewable and an economically cheaper method which ultimately requires the pursuit of raw materials. In solid state

*Author for correspondence: <roheena_abdullah@yahoo.com>. 
fermentation (SSF), the conditions required for growth are simple because these growth conditions resemble the natural habitat of many microorganisms' particularly filamentous fungi. The energy consumption is low, gives higher productivity, and the complex and sophisticated controlling system is not required to perform the solid state fermentation (Garcia et al. 2015).

\section{Materials and Methods}

The experiments were carried out in Department of Biotechnology, LCWU. Different fungal strains were isolated from various samples including soil, animal dung, bark according to Gupta et al. (2015) using plates containing Berg medium. The pretreatment of substrate like sugarcane bagasse was carried by alkali treatment method. The substrate is chopped in small pieces and sundried. The air-dried substrate was soaked in $1 \mathrm{~N} \mathrm{NaOH}$ solution for $24 \mathrm{hrs}$. After this duration washes the soaked sugarcane bagasse with the tap water and oven dry for $24 \mathrm{hrs}$ at $50^{\circ} \mathrm{C}$ (Maeda et al. 2011).

The solid-state fermentation was carried out using $10 \mathrm{~g}$ of sterilized substrate moistened with $10 \mathrm{ml}$ of minimal medium. One $\mathrm{ml}$ of conidial inoculum was added in sterilized substrate. All the flasks were placed in an incubator for $72 \mathrm{hrs}$ at $30^{\circ} \mathrm{C}$. After fixed duration $100 \mathrm{ml}$ of phosphate buffer ( $\mathrm{pH} 7$ ) was added in each flask to extract the enzyme and flasks were placed in shaking incubator for $60 \mathrm{~min}$. The suspension was filtered through muslin cloth and filtrate was further centrifuged at $6000 \mathrm{rpm}$ for $15 \mathrm{~min}$ in order to obtain clear supernatant. The supernatant was used for the determination of $\beta$-glucosidase.

Following fermentation media were tested for the production of beta-glucosidase using solid state fermentation. The $\mathrm{pH}$ of all media was maintained at $6 . \mathrm{M} 1: 5 \mathrm{~g}$ of rice straw and $5 \mathrm{~g}$ of wheat bran moistened with $10 \mathrm{ml}$ of mineral culture medium containing $(\mathrm{g} / \mathrm{l}): 3 \mathrm{~g} \mathrm{NaNO}, 0.1 \mathrm{~g}$ $\mathrm{KH}_{2} \mathrm{PO}_{4}, 0.5 \mathrm{~g} \mathrm{MgSO}_{4}, 0.5 \mathrm{~g} \mathrm{KCl} .2 \mathrm{H}_{2} \mathrm{O}$ (Sherief et al. 2010). M2: $10 \mathrm{~g}$ of pretreated saw dust moistened with $10 \mathrm{ml}$ of mineral salt media (MSM) containing (g/l) $0.8 \mathrm{~g} \mathrm{NaCl}, 0.8 \mathrm{~g} \mathrm{KCl}, 0.1 \mathrm{~g}$ $\mathrm{CaCl}_{2}, 2.0 \mathrm{~g} \mathrm{Na}_{2} \mathrm{HPO}_{4}, 0.2 \mathrm{~g} \mathrm{MgSO}_{4}, 0.1 \mathrm{~g} \mathrm{FeSO}_{4}, 8.0 \mathrm{~g}$ glucose, $2.0 \mathrm{~g} \mathrm{NH} \mathrm{H}_{4} \mathrm{Cl}, 1000 \mathrm{ml}$ distilled water (Khan and Singh 2011). M3: $10 \mathrm{~g}$ of corn straw moistened with $10 \mathrm{ml}$ of nutrient solution containing $1 \mathrm{~g}$ ammonium sulfate, $1 \mathrm{~g}$ magnesium sulfate heptahydrate and $1 \mathrm{~g}$ ammonium nitrate (Santos et al. 2016). M4: $10 \mathrm{~g}$ of pretreated sugarcane bagasse was moistened with $10 \mathrm{ml}$ of

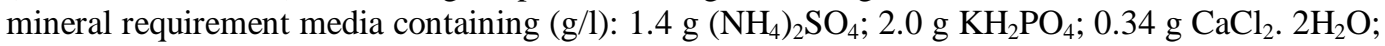
$0.30 \mathrm{~g} \mathrm{MgSO}_{4} .7 \mathrm{H}_{2} \mathrm{O} ; 0.005 \mathrm{~g} \mathrm{FeSO}_{4} .7 \mathrm{H}_{2} \mathrm{O} ; 0.0016 \mathrm{~g} \mathrm{MnSO}_{4} . \mathrm{H}_{2} \mathrm{O} ; 0.0014 \mathrm{~g} \mathrm{ZnSO}_{4} .7 \mathrm{H}_{2} \mathrm{O}$ and $0.002 \mathrm{~g} \mathrm{CoCl}_{2} \cdot 6 \mathrm{H}_{2} \mathrm{O}$ ( $\mathrm{Ng}$ et al. 2010). M5: $10 \mathrm{~g}$ of wheat bran moistened with $10 \mathrm{ml}$ of mineral

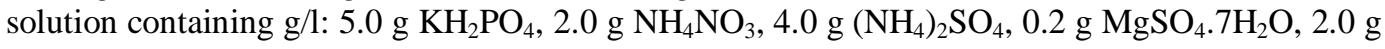
peptone, $2.5 \mathrm{~g}$ trisodium citrate and $1.0 \mathrm{~g}$ yeast extract (Bhatti et al. 2013). M6: $10 \mathrm{~g}$ of wheat straw moistened with $10 \mathrm{ml}$ of nutrient solution containing $(\mathrm{g} / \mathrm{l}): 1 \mathrm{~g}$ ammonium sulfate, $1 \mathrm{~g}$ magnesium sulfate heptahydrate and $1 \mathrm{~g}$ ammonium nitrate (Garcia et al. 2015).

$\beta$-glucosidase activity was determined according to Rajoka and Malik (1997). One unit of $\beta$-glucosidase is defined as "the amount of enzyme required to yield $1.0 \mu \mathrm{M}$ of $p$-nitrophenol within one minute under standard assay conditions" (Garcia et al. 2015). Total protein was estimated according to Bradford method (Bradford 1976).

All the data were tabulated and subjected to statistical analysis. Post Hoc multiple comparison test was used under one-way ANOVA. The software used for statistical analysis was SPSS version 23 .

\section{Results and Discussion}

The choice of appropriate strain plays pivotal role in the success of any fermentation process. For this purpose 20 different fungal strains were isolated and screened for $\beta$-glucosidase in solid state fermentation (data not shown). Among all the fungal strains the strain which exhibited 
highest $\beta$-glucosidase productivity (7.09 $\mathrm{IU} / \mathrm{ml} / \mathrm{min}$ ) along with $0.30 \mathrm{mg} / \mathrm{ml}$ total protein was selected. The selected strain was identified according to Diba et al. (2007). The selected strain was identified as Aspergillus niger and given the code Aspergillus niger MBT-2. The choice of suitable medium is a significant factor in the production of BG. Six different fermentation media were evaluated for the $\beta$-glucosidase (Fig. 1a). All other media gave less $\beta$-glucosidase production as compared to $\mathrm{M} 5(16.1 \mathrm{IU} / \mathrm{ml} / \mathrm{min})$. The reason might be that the capability of wheat bran for the maximal production of enzyme based on its chemical composition because it consists of significant amount of carbohydrates, fats, proteins and fiber which are necessary for the growth of fungi as well as BG production. In contrast the decline in BG production in other media was either due to the shortage of certain substances in the media that were crucial for growth of fungi as well enzyme productivity (Singhania et al. 2011).

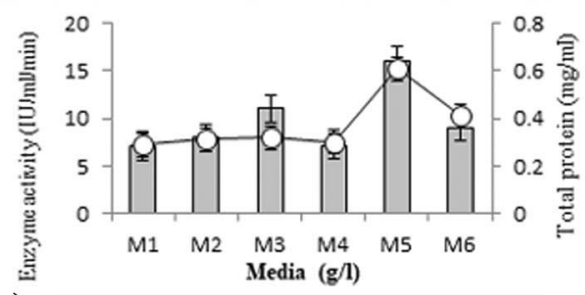

(a)

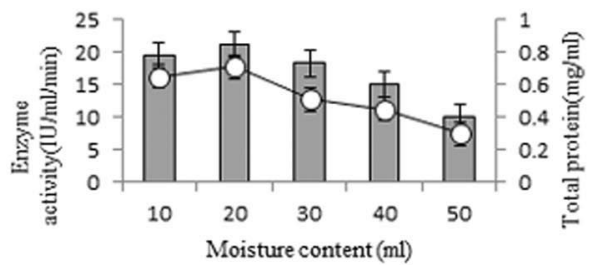

(c) $\square$ Enzyme activity - -Total protein

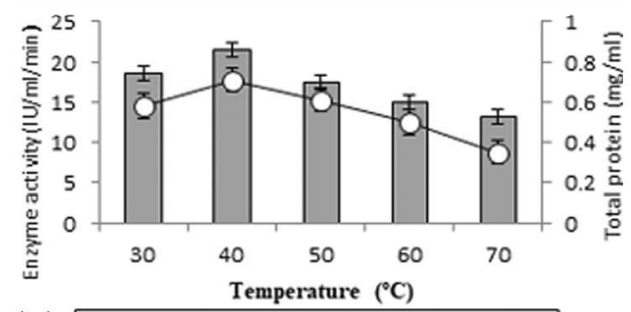

(e) $\square$ Enzyme activity $\multimap-$-Total protein

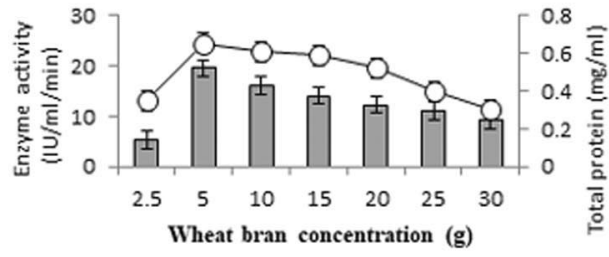

(b)

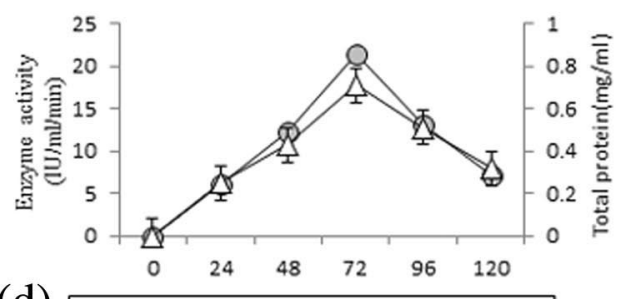

(d)
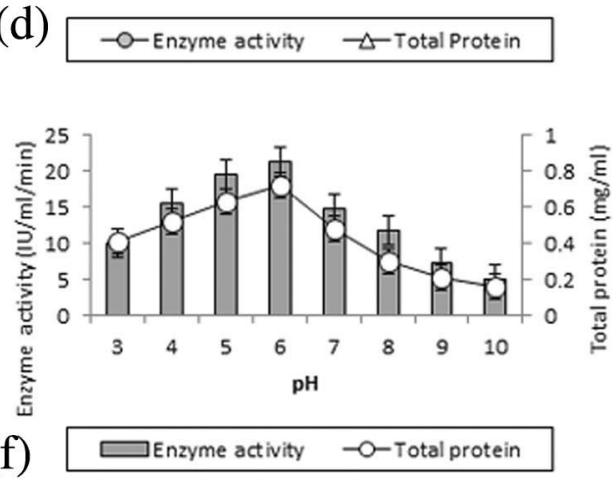

Fig.1. Impact of different physical parameters on the production of $\beta$-glucosidase. (a) Fermentation media,

(b) substrate concentration, (c) moisture content, (d) incubation time and (e) incubation temperature.

Substrate concentration plays a crucial role for the enhanced and better production of enzyme under optimal conditions. The influence of varying concentration $(2.5-30 \mathrm{~g})$ of wheat bran was noted (Fig. 1b). The optimal production of beta-glucosidase was obtained when $5 \mathrm{~g}$ of wheat bran was used. The greater amount of substrate concentration reduces the enzyme production because substrates molecules were very closely associated around the molecules of enzyme. They might be 
attached to the regions on the enzyme, which might not be the active site or blocked the active site, hence, enzyme production stopped (Dixon 1971). The varying moisture content ranging from $10-50 \mathrm{ml}$ was tested. The highest production of $\beta$-glucosidase was obtained in the presence of $20 \mathrm{ml}$ moistening agent (Fig. 1c). Above or below this level reduction in the production of enzyme was recorded. At higher moisture level substrate particles stick together which cease proper supply of oxygen in substrate for the growth of microorganism (Sharanappa et al. 2011).

The fermentation was carried out from $0-120 \mathrm{hrs}$ (Fig. 1d). The maximal production of the $\beta$-glucosidase was found at $72 \mathrm{hrs}$. Further rise or fall resulted decline in enzyme production. This is due to the reason that during the early hours of incubation, spores have the capability to germinate and form mycelia. The increase in mycelia, may lead to the better enzyme production (Tu et al. 2007). The influence of varying temperature greatly affects the enzyme activity. The impact of variation in incubation temperature $\left(30-70^{\circ} \mathrm{C}\right)$ was evaluated (Fig. 1e). The optimal $\beta$-glucosidase production $(21.4 \mathrm{IU} / \mathrm{ml} / \mathrm{min})$ along with $0.71 \mathrm{mg} / \mathrm{ml}$ total protein content was obtained at $40^{\circ} \mathrm{C}$. The gradually decline in enzyme production was noted with the increase or decrease in incubation temperature. Likelihood the reason for less productivity of BG above the optimal point is evaporation of moisture resulting in decline of moisture contents; which ultimately result decrease in fungal growth as well as enzyme production (Fawole and Odunfa 2003).

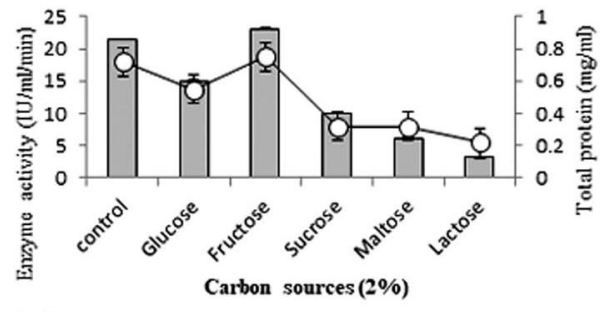

(a) DEnzyme activity -O-Total protein
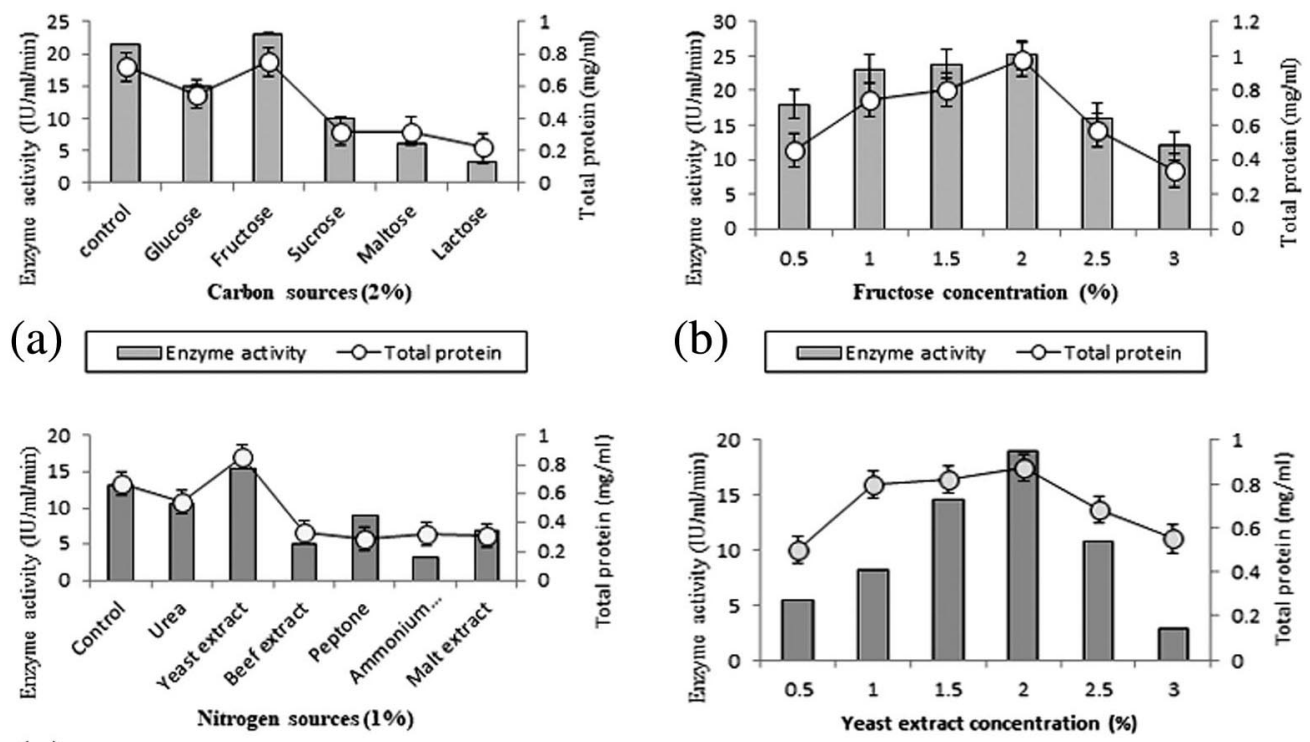

(c)

Nitrogen sources $(1 \%)$

(b)
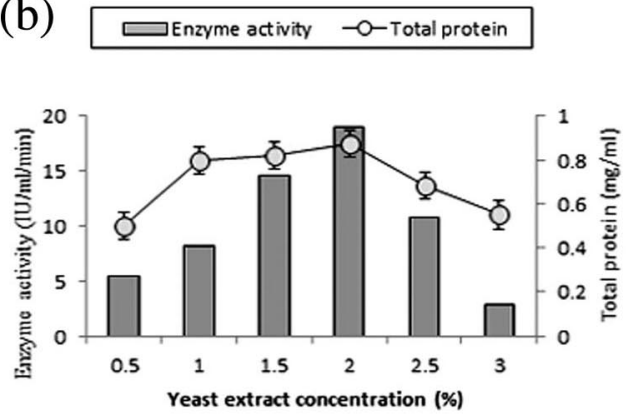

(d) $\square_{\text {Total protein }}^{-0-\text { Enzyme activity }}$

Fig. 2. Impact of different nutritional parameters on the production of $\beta$-glucosidase. (a) Carbon sources, (b) fructose concentration, (c) nitrogen sources and (d) yeast extract concentration

In order to optimize the process parameters, $\mathrm{pH}$ was found to be the very critical parameter for the better enzyme production. The different $\mathrm{pH}$ values $(3-10)$ were evaluated for the $\beta$ glucosidase production. The enzyme productivity increases gradually from $3-6 \mathrm{pH}$ (Fig. 1f). The enzyme production was found to move towards the decline after the optimum $\mathrm{pH}$ 6.0. The same results were reported by Olajuyigbe et al. (2016) who found that the enzyme production increases 
by fungi form $\mathrm{pH} 3-6$. Perhaps the reason was that the ionic state of substrate changes which greatly affect the growth of microorganisms.

Carbon is the important component present in all living organisms. The breakdown process of carbon sources release energy. This released energy is then utilized by the microorganisms for their better growth and development. Impact of different carbon sources on $\beta$-glucosidase production was evaluated (Fig. 2a). The carbon sources screened at $1 \%$ level include glucose, fructose, sucrose, maltose and lactose. The maximum $\beta$-glucosidase production was obtained when fructose was added in the medium. So, different concentrations $(0.5-3.0)$ of fructose were tested. Two Per cent fructose gave optimal $\beta$-glucosidase productivity (Fig. $2 b$ ). The present findings are similar to the results reported by Shahzadi et al. (2014) who reported fructose as a best carbon source for beta-glucosidase production. The influence of different nitrogen sources including urea, yeast extract, beef extract, peptone, ammonium sulfate, malt extract was evaluated on the beta-glucosidase production (Fig. 2c). Two per cent yeast extract proved to be the best nitrogen source for maximal beta-glucosidase production (Fig. 2d). The present findings are similar to the results of Shahriarinour (2011 who reported that yeast extract was best nitrogen source for beta-glucosidase production.

From the present study it may be concluded that the exploitation of agricultural by products as a substrate lessens the production cost of enzyme and makes the process economical. The Aspergillus niger MBT2 has promising potential of bioconversion of low-cost material into valuable product like $\beta$-glucosidase.

\section{References}

Ahmed A, Nasim F, Batool K and Bibi A 2017. Microbial $\beta$-glucosidase: sources, production and applications. J. Appl. Environ. Microbiol. 5: 31-46.

Amouri B and Gargouri A 2006. Characterization of a novel $\beta$-glucosidase from a Stachybotrys strain. Biochem. Eng. J. 32: 191-197.

Bhargav S, Panda BP, Ali M and Javed S 2008. Solid-state fermentation: An overview. Chem. Biochem. Eng. Q. 22: 49-70.

Bhatti HN, Batool S and Afzal N 2013. Production and characterization of a novel $\beta$-glucosidase from Fusarium solani. Int. J. Agric. Biol. 15: 45-98.

Bradford MM 1976. A rapid and sensitive method for the quantitation of microgram quantities of protein utilizing the principle of protein-dye binding. Anal. Biochem. 72: 248-254.

Diba K, Kordbacheh P, Mirhendi S, Rezaie S and Mahmoudi M 2007. Identification of Aspergillus species using morphological characteristics. Pak. J. Med. Sci. 23: 867.

Dixon, M 1971. Webb EC. Enzymes $2^{\text {nd }}$ ed. Longman group Ltd, London. pp. 67-188.

Fawole O and Odunfa S 2003. Some factors affecting production of pectic enzymes by Aspergillus niger. Int. Biodeterior. Biodegradation. 52: 223-227.

Garcia NFL, Santos FRDS, Gonçalves FA, Paz MFD, Fonseca GG and Leite RSR 2015. Production of $\beta$-glucosidase on solid-state fermentation by Lichtheimia ramosa in agroindustrial residues: Characterization and catalytic properties of the enzymatic extract. Electron. J. Biotechnol. 18: 314-319.

Gupta C, Jain P, Kumar D, Dixit A and Jain R 2015. Production of cellulase enzyme from isolated fungus and its application as efficient refining aid for production of security paper. Int. J. Appl. Microbiol. Biotechnol. Res. 3: 11-19.

Khan JA and Singh SK 2011. Production of cellulase using cheap substrates by solid state fermentation. Int. J. Plant. Anim. Environ. Sci. 1: 179-187.

Leite RS, Gomes E and Da Silva R 2007. Characterization and comparison of thermostability of purified $\beta$-glucosidases from a mesophilic Aureobasidium pullulans and a thermophilic Thermoascus aurantiacus. Process. Biochem. 42: 1101-1106. 
Maeda RN, Serpa VI, Rocha VA, Mesquita RA, Santa Ann LM, De Castro AM, Driemeier CE, Pereira N and Polikarpov I 2011. Enzymatic hydrolysis of pretreated sugar cane bagasse using Penicillium funiculosum and Trichoderma harzianum cellulases. Process. Biochem. 46: 1196-1201.

Ng IS, Li CW, Chan SP, Chir JL, Chen PT, Tong CG, Yu SM and Ho TH 2010. High-level production of a thermoacidophilic $\beta$-glucosidase from Penicillium citrinum ys40-5 by solid-state fermentation with rice bran. Bioresour. Technol. 101: 1310-1317.

Olajuyigbe FM, Nlekerem CM and Ogunyewo OA 2016. Production and characterization of highly thermostable $\beta$-glucosidase during the biodegradation of methyl cellulose by Fusarium oxysporum. Biochem. Res. Int. 2016: 413-487.

Rajoka MI and Malik KA 1997. Cellulase production by Cellulomonas biazotea cultured in media containing different cellulosic substrates. Bioresour. Technol. 59: 21-27.

Ramos-Ibarra JR, Miramonates AA, Arriola E, Guatemala G and Corona RI 2017. Production of hydrolytic enzymes by solid-state fermentationwith new fungal strains using orange by products. Rev. Mex. Ing. Quim. 16: 19-31.

Raza F, Raza NA, Hameed U, Haq I and Maryam I 2011. Solid state fermentation for the production of $\beta$-glucosidase by co-culture of Aspergillus niger and Aspergillus oryzae. Pak. J. Bot. 43: 75-83.

Santos F, Garcia NFL, Dapaz MF, Fonseca GG and Leite RSR 2016. Production and characterization of $\beta$-glucosidase from Gongronella butleri by solid-state fermentation. Afr. J. Biotechnol. 15: 633-641.

Shahriarinour M, Wahab MNA, Mohamad R, Mustafa S and Ariff AB 2011. Effect of medium composition and cultural condition on cellulase production by aspergillus terreus. Afr. J. Biotechnol. 10: 7459-7467.

Shahzadi T, Anwar Z, Iqbal Z, Anjum A, Aqil T, Afzal B, Kamran M, Mehmood S and Irshad M 2014. Induced production of exoglucanase, and $\beta$-glucosidase from fungal co-culture of Trichoderma viride and Ganoderma lucidum. Adv. Biosci. Biotechnol. 5: 426-433.

Sharanappa A, Wani KS and Patil P 2011. Bioprocessing of food industrial waste for $\alpha$ - amylase production by solid state fermentation. Int. J. Adv. Biotechnol. Res. 2: 473-480.

Sherief A, El-Tanash A and Atia N 2010. Cellulase production by Aspergillus fumigatus grown on mixed substrate of rice straw and wheat bran. Res. J. Microbiol. 5: 199-211.

Singhania RR, Patel AK, Sukumaran RK, Larroche C and Pandey A 2013. Role and significance of betaglucosidases in the hydrolysis of cellulose for bioethanol production. Bioresour. Technol. 127: 500-507.

Singhania RR, Sukumaran RK, Rajasree KP, Mathew A, Gottumukkala L and Pandey A 2011. Properties of a major $\beta$-glucosidase-bgl1 from Aspergillus niger nii-08121 expressed differentially in response to carbon sources. Process. Biochem. 46: 1521-1524.

Tu M, Chandra RP and Saddler JN 2007. Evaluating the distribution of cellulases and the recycling of free cellulases during the hydrolysis of lignocellulosic substrates. Biotechnol. Prog. 23: 398-406.

Zang X, Liu M, Fan Y, Xu J, Xu X and Li H 2018. The structural and functional contributions of $\beta$-glucosidase-producing microbial communities to cellulose degradation in composting. Biotechnol. Biofuels. 11: 1-13. 